\title{
Practical Experiences in a Classroom as a Learning Aid in the Component Mineral Concentration in a Mining Course of the Federal Institute of Amapá, Brazil
}

DANTAS, Antônio de Pádua Arlindo ${ }^{[1]}$, FECURY, Amanda Alves ${ }^{[2]}$, OLIVEIRA, Euzebio de ${ }^{[3]}$, DENDASCK, Carla Viana ${ }^{[4]}$, MATTOS, Claudio Alberto Gellis de ${ }^{[5]}$

DANTAS, Antônio de Pádua Arlindo; et.al. Practical Experiences in a Classroom as a Learning Aid in the Component Mineral Concentration in a Mining Course of the Federal Institute of Amapá, Brazil. Multidisciplinary Scientific Journal. Year 03, Ed. 07, Vol. 07, pp. 05-12, July of 2018. ISSN: 2448-0959

\begin{abstract}
The education has been developed with a content and disconnected logic, without a direct relation with the social environment. The new methodologies of education should make a relation between what is learned in the classroom and what the student experiences in his daily life. Constructing a technical high school where the theory and practice are interconnected would probably generate a greater understanding on the part of the students and a greater insertion in the labor market in the chosen área. This work aims to verify if practical experiences in the classroom help the learning in the component Mineral Concentration in a regular mining course of the Federal Institute of Amapá. Theoretical and practical classes of the same content were given in identical and compared classes. There seems to be a learning in both ways of teaching, according to the results obtained. Traditional learning seems to arouse less interest than the (practical) differential, making it appear that there was greater retention of knowledge due to lower error rate. It seems that allying traditional to practical teaching would improve the learning rate in the Mineral Concentration component of the Federal Institute of Amapá.
\end{abstract}

Keywords: Theoretical Learning, Practical Learning, Education.

\section{Introduction}

According to the Law of Brazilian National Curricular Guidelines for Basic Education in the part that talks about the National Curricular Guidelines for the Technical Professional Education of Medium 
Level, item Organization of Distance Courses, with Technological Mediation, and Parameters of Time Work Face-to-face which talks about the importance of the working conditions of the presence poles. In these units we carry out face-to-face activities such as assessments, follow-up and internship orientations, orientation to students, defense of course completion work, practical classes in specific environments, such as laboratories, workshops, workshops and others; explaining the importance of the existence of this structure at the time of authorization of the operation of courses (BRASIL, 2012).

The teaching of sciences has been developed with a logistical and dissociated logic, without a direct relation with the social environment; this thinking seems to cover all levels of teaching and disciplines of the country. This teaching, based on a traditionalist model, is still used by many faculty members, which can hinder and discourage learning and interest on the part of the subjects. formation (CARRIJO e BAPTISTA, 2016).

The new methodologies of education should make a relation between what is learned in the classroom and what the student experiences in his daily life. Regarding the teaching of Natural Sciences, it is observed that, in general, students have faced difficulties in assimilating content in this area of ??knowledge. Such problems are likely to occur due to the absence of practical activities in Natural Science classes in elementary school as well as the lack of teacher preparation (CARRIJO e BAPTISTA, 2016).

Building a vocational high school where the theory and practice are interconnected would probably generate a greater understanding on the part of the students and a greater insertion in the labor market in the chosen area (OLIVEIRA, 2011)

Learning (apprehending) in its broadest sense can be described as an ongoing process of acquiring new knowledges (GONÇALVES, 2011). The evaluation of this learning consists in detecting the knowledge learned as well as the difficulties resulting from this process. The teacher can use these variables in order to plan actions as a means to facilitate learning (CARNEIRO et al., 2017).

The theory, applied through conceptual classes, is placed as a teaching tool, which will allow students to form a basis on which new teaching methodologies can be used (CAVAGIS et al., 2017). On the other hand, the practice, in some controlled situations, presents a valuable resource by exposing the student to real situations. Such situations may cause competencies to be permanently established (FELIZARDO e CARDOSO, 2017).

There seems to be a gap between high school, technical or not, and higher education. Universities experts "think" of education as an applied science, generate theoretical knowledge and instruct high school teachers to put it into practice Over the years, there seems to be a migration to a partnership where high schools as well as generating teaching-learning practices and theories (HARDOIM et al., 2017).

In this sense there seems to be a movement that distances the school teaching from standard learning procedures, adding (or replacing them) with alternatives that (re) approximate and arouse student interest in learning (MURIGI et al., 2017). Resources different from traditional classroom classes tend to show results where the student discerns between new situations and manages to build his own knowledge, carrying with greater capacity of retention and complexity (NICOLA e PANIZ, 2016). 
In order for an integration between traditional and practical classes to be possible, it is necessary for the teacher to develop his / her knowledge in this sense, putting the learned content added to different practices (PACHECO et al., 2017). There may be an absence of interest among teachers, based on many different factors (which are not the focus of this work), in order to be updated and to seek new and different ways of teaching the necessary content for a given class (SANTOS et al., 2017).

Some projects achieve success in this process of theoretical-practical aggregation, bringing together teachers (schools) and researchers (universities), making use of new practices added to the traditional, making classes contextualized and closer to the reality of the student (SILVA et al., 2017).

Therefore, it seems that, if there is a correlation between theory and practice, a lasting relationship will be established in the student, which could generate a greater capacity for knowledge, discernment and transversality of acquired knowledge (NICOLA e PANIZ, 2016).

This work aims to verify if practical experiences in the classroom help the learning in the component Mineral Concentration in a regular mining course of the Federal Institute of Amapá.

\section{Method}

A theoretical class was given to a group of 4th year of the technical course in mining and a practical class, of same content, with the same workload for another class of the same course, of the same year. Before the beginning of each class, for each class, an evaluation instrument was applied on previous knowledge, containing five questions. After the end of both classes, for both classes, another evaluation instrument was applied to quantify knowledge, also containing five questions. The evaluative tools will be compared (pre and post class) and compiled in an Excel spreadsheet, a component of the Microsoft Corporation Office suite. They will then be analyzed among themselves and transversally.

Regarding the ethical aspects, this research will use the Term of Assent, which does not exempt the Term of Free and Informed Consent (signed by the parents or legal guardian of the minor). The study faithfully followed the ethical precepts contained in the Child and Adolescent Statute (ECA). This study took into account the guidelines contained in resolution CNS, No. 466/2012, MS, Brazil.

\section{Results}

Figure 1 shows the number of unanswered questions in theoretical and practical pre-assessments and in post-theoretical and practical assessments. The highest level of unanswered questions occurred in pretheorical evaluations. In both post-theoretical evaluations there was a significant drop in unanswered questions. 


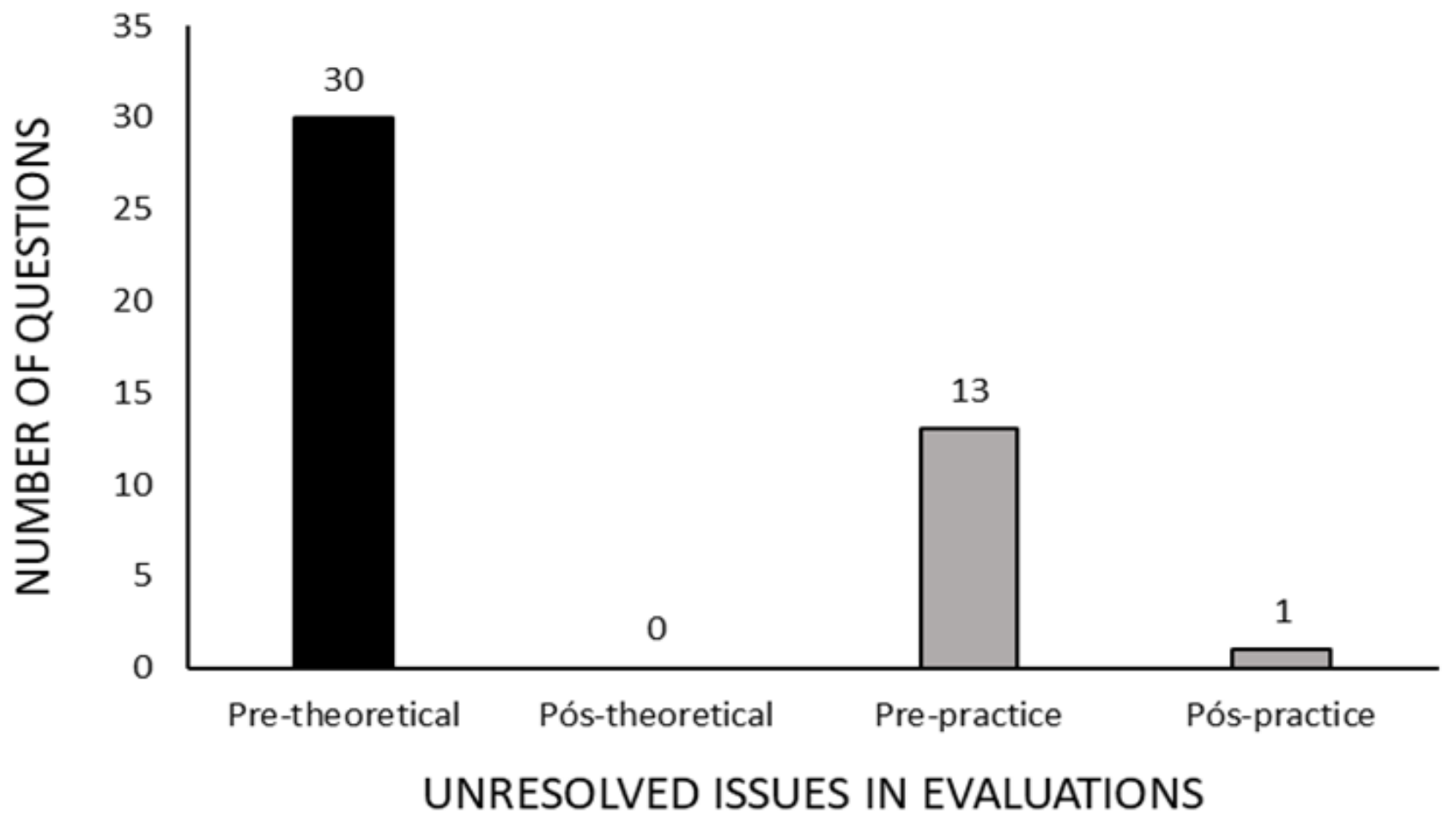

Figure 1: Shows the number of unanswered questions in theoretical and practical pre-assessments and in post-theoretical and practical assessments.

Figure 2 shows the percentage of erroneous questions in theoretical and practical pre-assessments and in post-theoretical and practical assessments. The data show a decrease of $4 \%$ between the errors made between the pre and post theoretical evaluation. The decrease of errors between pre and post practice evaluations was higher, $23 \%$. 


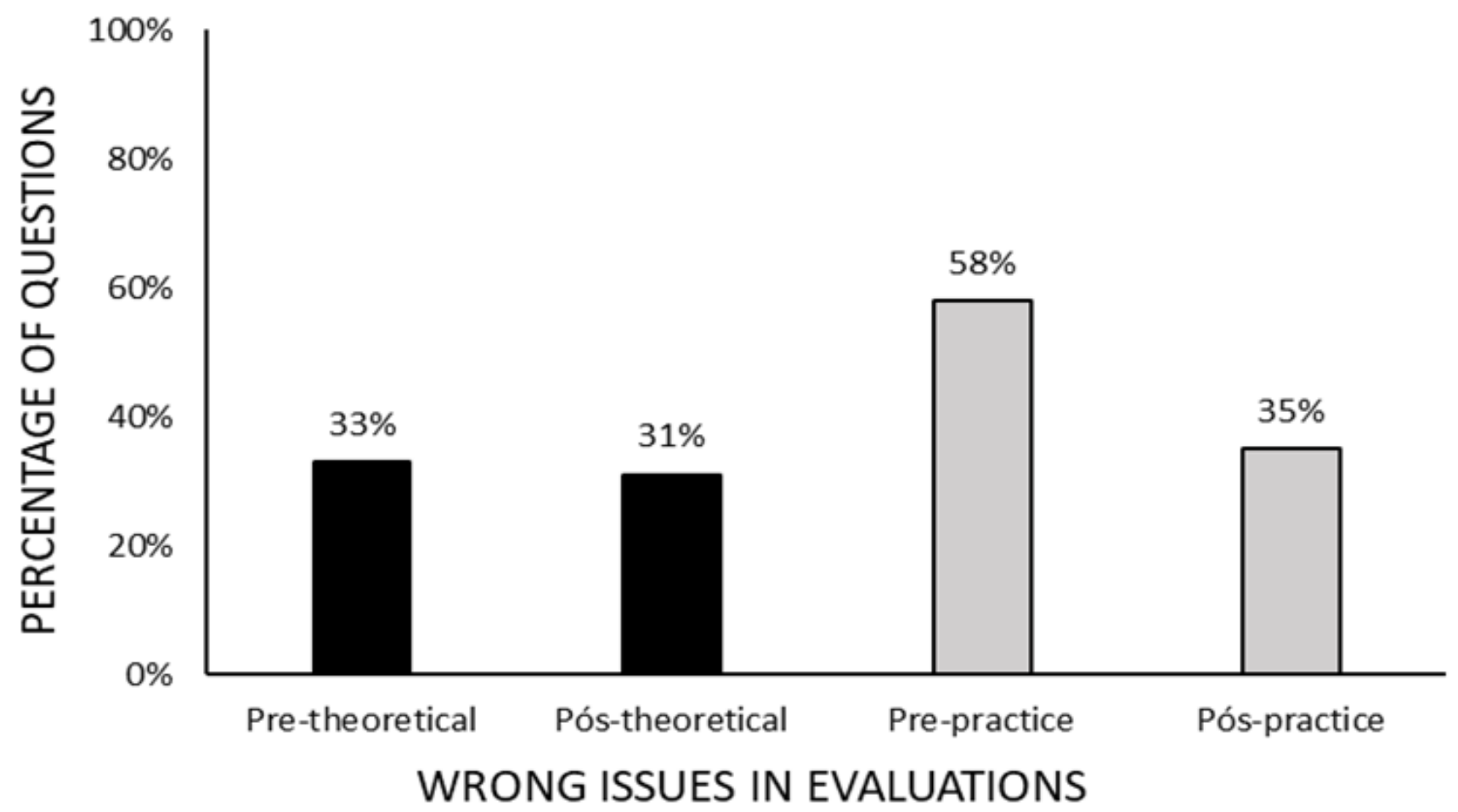

Figure 2: Shows the percentage of wrong questions in theoretical and practical pre-assessments and in post-theoretical and practical assessments.

\section{Discussion}

The results presented a greater number of unanswered theoretical questions in the theoretical preassessment than pre-evaluation in practice. This is possibly due to a lack of motivation presented by the current generation with the way content is presented and also how it is "charged" by educational institutions, as well as the need for learning is seen (MUCH et al., 2018).

The reduction of errors in the questions of pre and post-theoretical evaluations seems to show that there is learning, even with traditional classes (CAVAGIS et al., 2017). The same happens when we observe the mistakes made between pre and post practice evaluations. The lower error rate in this practical group seems to clarify the important role of new and differentiated practices of technological teaching (NICOLA e PANIZ, 2016; FELIZARDO e CARDOSO, 2017; SILVA et al., 2017).

\section{Conclusion}

There seems to be a learning in both ways of teaching, according to the results obtained.

Traditional learning seems to arouse less interest than the (practical) differential, making it appear that there was greater retention of knowledge due to the lower error rate in the latter.

It seems that allying traditional to practical teaching would improve the learning rate in the Mineral Concentration component of the Federal Institute of Amapá. 
Further studies are needed with a larger group of students to establish an exact correlation between both forms of teaching.

\section{References}

BRASIL. Resolução CNE/CEB 6/2012. CNE/CEB. Brasília: Ministério da Educação e Cultura: 12 p. 2012.

CARNEIRO, V. F. et al. Avaliação da aprendizagem: concepções e olhares de docentes do curso de odontologia. Revista Ibero-Americana de Estudos em Educação, v. 12, n. 2, p. 900-915, 2017.

CARRIJO, R. F.; BAPTISTA, L. V. Uma (re)aproximação da teoria à realidade prática de Ensino, Pesquisa e Extensão da UEG. . III Congresso Aulas experimentais no Ensino de Ciências. CEPE. Pirenopolis GO: Universidade Estadual de Goiás 2016.

CAVAGIS, A. D. M. et al. Formação continuada de professores do Ensino Fundamental I em ciências da natureza e matemática. Rev. Ciênc. Ext., v. 13, n. 3, p. 146-159, 2017.

FELIZARDO, H.; CARDOSO, A. F. Técnica de espelhamento nas aulas de prática laboratorial no ensino de Enfermagem. Indagatio Didactica, v. 9, n. 1, 2017.

GONÇALVES, C. B. Educação a Distância: A Aprender Online. Rev. ARETÉ v. 4, n. 6, p. 24-34 2011.

HARDOIM, R. L. A.; SILVA, T. L.; CHAVES, I. M. B. Narrativas de formação docente no prodocência e no PIBID. Revista @mbienteeducação, n. 1, p. 74-84, 2017.

MUCH, L. N.; BONFADA, K. M.; TERRAZZAN, E. A. Mudança na prática docente: incentivando o protagonismo discente RELACult - Revista Latino-Americana de Estudos em Cultura e Sociedade, v. 4, p. 1-9, 2018.

MURIGI, L. C. et al. O Caderno do Professor do Estado de São Paulo e o Discurso de Autoajuda nas Metodologias de Ensino de Língua Portuguesa. Revista Eletrônica de Letras (Online), v. 10, n. 10, 2017.

NICOLA, J. A.; PANIZ, C. M. A importância da utilização de diferentes recursos didáticos no ensino de biologia. Infor, Inov. Form., Rev. NEaD, v. 2, n. 1, p. 355-381, 2016.

OLIVEIRA, P. W. S. Construção de Identidades Profissionais: da Formação Profissional à Vivência da Inserção no Mercado de Trabalho. Revista LABOR v. 1, n. 6, 2011.

PACHECO, W. R. D. S.; BARBOSA, J. P. D. S.; FERNANDES, D. G. A Relação Teoria e Prática no Processo de Formação Docente. Revista de Pesquisa Interdisciplinar, n. 2, p. 332- 340, 2017.

SANTOS, J.; OLIVEIRA, D.; LIMA, E. Turismo e formação técnica: Relação entre teoria e prática nos cursos técnicos em eventos do Campus Brasília do IFB. Revista Turismo \& Desenvolvimento, n. 27/28, p. 1757 - 1770, 2017. 
SILVA, F. R. D. et al. Experimentação em Ciências: Verificando a Relação entre a Teoria e a Prática no Ensino de Genética em uma Escola Pública no Município de Vitória de Santo Antão - Pe. Rev. Ciênc. Ext., v. 13, n. 3, p. 160-170, 2017.

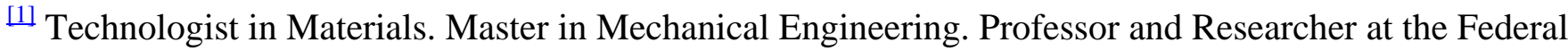
Institute of Amapá - IFAP

${ }^{[2]}$ Biomedical. PhD in Tropical Diseases. Professor and Researcher at the Federal University of Amapá, AP. Collaborating researcher at the Tropical Medicine Nucleus of UFPA (NMT-UFPA).

${ }^{[3]}$ Biologist. PhD of Medicine / Tropical Diseases. Professor and Researcher at the Federal University of Pará - UFPA.

${ }^{[4]} \mathrm{PhD}$ in Clinical Psychoanalysis, Researcher by the Center for Research and Advanced Studies.

[5] Biologist. PhD in Theory and Research of Behavior. Professor and Researcher of the Federal Institute of Amapá - IFAP. Collaborating researcher at the Nucleus of Fisheries and Aquaculture Studies at the Federal University of Amapá, (NEPA-UNIFAP).

\section{PUBLIQUE SEU ARTIGO CIENTÍFICO EM:}

https://www.nucleodoconhecimento.com.br/enviar-artigo-cientifico-para-submissao 